\title{
Silicon nanowire array architecture for heterojunction electronics
}

\author{
(C) M.M. Solovan ${ }^{1}$, V.V. Brus ${ }^{2}$, A.I. Mostovyi ${ }^{1}$, P.D. Maryanchuk ${ }^{1}$, \\ I.G. Orletskyi ${ }^{1}$, T.T. Kovaliuk ${ }^{1}$, S.L. Abashin ${ }^{3}$
}

${ }^{1}$ Department of Electronics and Energy Engeneering, Chernivtsi National University,

58012 Chernivtsi, Ukraine

${ }^{2}$ Institute for Silicon Photovoltaics, Helmholtz-Zentrum Berlin für Materialien und Energie GmbH, 12489 Berlin, Germany

${ }^{3}$ Department of physics, National Aerospace University „Kharkiv Aviation Institute“, 61070 Kharkiv, Ukraine

E-mail: m.solovan@chnu.edu.ua

(Получена 20 сентября 2016 г. Принята к печати 29 сентября 2016 г.)

Photosensitive nanostructured heterojunctions $n$-TiN $/ p$-Si were fabricated by means of titanium nitride thin films deposition ( $n$-type conductivity) by the DC reactive magnetron sputtering onto nanostructured single crystal substrates of $p$-type $\mathrm{Si}(100)$.

The temperature dependencies of the height of the potential barrier and series resistance of the $n-\mathrm{TiN} / p-\mathrm{Si}$ heterojunctions were investigated. The dominant current transport mechanisms through the heterojunctions under investigation were determined at forward and reverse bias.

The heterojunctions under investigation generate open-circuit voltage $V_{o c}=0.8 \mathrm{~V}$, short-circuit current $I_{s c}=3.72 \mathrm{~mA} / \mathrm{cm}^{2}$ and fill factor $F F=0.5$ under illumination of $100 \mathrm{~mW} / \mathrm{cm}^{2}$.

DOI: $10.21883 /$ FTP.2017.04.44354.8407 